\title{
PENGARUH KOMPENSASI DAN PENEMPATAN KERJA TER- HADAP KEPUASAN KERJA DAN DAMPAKNYA PADA KINERJA TENAGA KEPENDIDIKAN UNIVERSITAS “MJ”
}

Penulis

Institusi

Email Korespondensi

DOI

\section{Fathurachman; M. Adila Rossa}

Fakultas Ilmu Sosial dan Ilmu Politik, Universitas Muhammadiyah Jakarta

ben_faturahman@yahoo.co.id

https://doi.org/10.53947/perspekt.v1i1.55
Kata Kunci:

Kompensasi Penempatan Kerja Kepuasan Kerja Kinerja

Keywords:

Compensation Job Placement Job satisfaction Performance

\begin{abstract}
Abstrak
Penelitian ini bertujuan untuk mengetahui pengaruh kompensasi dan penempatan kerja terhadap kepuasan dan dampaknya terhadap kinerja tenaga kependidikan Universitas "MJ". Metode penelitian menggunakan pendekatan kuantitatif dengan metode explanatory. Populasi penelitian adalah Tenaga Kependidikan Univeritas "MJ" dengan sampel sebanyak 69 responden. Teknik pengambilan sampel dilakukan dengan teknik sample random sampling. Metode pengumpulan data menggunakan kuesioner. Data yang diperoleh kemudian diolah dengan menggunakan alat bantu WarpPLS versi 7.0. Teknik analisis yang digunakan meliputi; merancang inner model, merancang outer model, mengkonstruksi diagram jalur, mengkonversi diagram jalur menjadi persamaan, estimasi parameter, goodness of fit, dan pengujian hipotesis, Hasil analisis memberikan kesimpulan (a) kompensasi berpengaruh signifikan dan positif terhadap kepuasan kerja, (b) Penempatan kerja berpengaruh signifikan dan positif terhadap kepuasan kerja, (c) Kompensasi berpengaruh tetapi tidak signifikan terhadap kinerja, (d) Penempatan kerja berpengaruh signifikan dan positif terhadap kinerja, (e) Kepuasan kerja berpengaruh signifikan dan positif terhadap kinerja, (f) Kompensasi berpengaruh signifikan dan positif terhadap penempatan kerja, dan (g) Kepuasan kerja memberikan peranan yang baik sebagai variabel intervening berpengaruh signifikan terhadap kinerja karyawan.
\end{abstract}

\footnotetext{
Abstract

This study aims to determine the effect of compensation and job placement on satisfaction and its impact on the performance of the "MJ" University education staff. The research method uses a quantitative approach with an explanatory method. The study population was the "MJ" University Education Personnel with a sample of 69 respondents. The sampling technique was carried out using a random sampling technique. Methods of data collection using a questionnaire. The data obtained were then processed using the WarpPLS version 7.0 tool. The analytical techniques used include; designing inner models, designing outer models, constructing path diagrams, converting path diagrams into equations, parameter estimation, the goodness of fit, and hypothesis testing,
} 


\section{PENDAHULUAN}

Universitas "MJ" mempunyai visi menjadi perguruan tinggi yang terkemuka, modern. Dan Islami di tahun 2025. Misi yang akan dicapai yaitu menciptakan universitas yang unggul di bidang pendidikan dan kemuhammadiyahan, dengan menerapkan teknologi dalam penyelengaraan pendidikan berdasarkan nilai-nilai Islam. Pencapaian visi dan misi Universitas "MJ" tersebut secara langsung membutuhkan sumber daya manusia, yaitu tenaga kepedidikan. Kinerja tenaga kependidikan merupakan faktor penting bagi pencapaian visi misi Universitas “MJ”. As'ad dalam Sudaryono (2017:67) mengatakan bahwa "kinerja adalah pencapaian keberhasilan seseorang dalam menyelesaikan pekerjaan menurut standar yang berlaku dan dapat dilihat dari aktivitas yang di-lakukan dalam usahanya menyelesaikan tugas-tugas yang telah diberikan”.

Pengelolaan tenaga kependidikan merupakan salah satu faktor penting terhadap keberhasilan pengelolaan Universitas "MJ". Kinerja tenaga kependidikan harus dioptimalkan sehingga menjadi sistem yang mendukung bagi pimpinan dalam mencapai visi dan misi. Salah satu aspek penting terhadap kinerja untuk mencapai tujuan adalah kepuasan kerja tenaga kependidikan. Musolli dan Majang Palupi (2018) menyimpulkan "bahwa kepuasan kerja berpengaruh secara signifikan dan positif terhadap kinerja tenaga kependidikan tetap Universitas “MJ”. Kepuasan kerja merupakan variabel yang dapat dipertimbangkan Universitas "MJ" dalam mengoptimalkan kinerja tenaga kependidikanya, seperti yang disampaikan Hasibuan (2016:202) "bahwa kepuasan kerja merupakan perilaku yang menyenangi dan menyayangi pekerjaan, sehingga dapat terlihat dari output kerja yang dihasilkan".

Aspek lain yang juga harus diperhatikan oleh Universitas "MJ" adalah kompensasi. Kompensasi adalah usaha organisasi untuk memaksimalkan hasil kerja, semangat serta kepuasan kerja. Kompensasi yang bagus dapat meningkatkan kepuasan bagi tenaga kependidikan sehingga bisa mendapatkan dan mengefektifkan tenaga kependidikan yang berkualitas. Menurut Milton L Rock dalam Gaol Jimmy (2014: 310) “masalah yang kerap kali muncul adalah bagaimana menghadirkan situasi yang mengarahkan orang-orang dalam bekerja sehingga organisasi dapat berkembang. Faktor penting dari situasi ini adalah kompensasi”.

Dalam upaya mengoptimalkan kinerja, ketelitian dalam menempatkan tenaga kependidikan adalah aspek yang penting juga. Penempatan tenaga kependidikan harus didasarkan pada penilaian terhadap kebutuhan dan tujuan organisasi. Dengan penempatan yang selektif dan tepat akan membuat kinerja tenaga kependidikan lebih baik. Sunyoto (2012:122) mendefinisikan "penempatan kerja sebagai proses pengisian atau penugasan kembali tenaga kependidikan pada jabatan yang berbeda”. Penempatan merupakan kebijakan organisasi dalam mengoptimalkan kinerja tenaga kependidikan di posisi yang paling tepat dengan tujuan organisasi dan kemampuannya. Dengan penempatan yang tepat, kreativitas, semangat dan prestasi kerja dapat dioptimalkan. Penelitian yang dilakukan oleh Beni Yulizar (2014) diperoleh kesimpulan bahwa, "penempatan terhadap kepuasan kerja mempunyai pengaruh 
yang berarti pada pegawai pada Kantor Dinas Sosial Provinsi Sumatera Barat". Selain itu, Leonardo William Goni dkk (2015) memberikan kesimpulan "bahwa ada pengaruh positif penempatan kerja terhadap terhadap kinerja karyawan pada PT. Bank Sulutgo Kantor Pusat Manado".

Berdasarkan uraian di atas, menarik untuk dilakukan penelitian dengan judul "Pengaruh Kompensasi dan Penempatan Kerja terhadap Kepuasan Kerja dan dampaknya pada Kinerja tenaga kependidikan Universitas 'MJ' “.

\section{KAJIAN LITERATUR}

\section{KINERJA}

Menurut Izhari dkk (2019:2), "kinerja merupakan perbandingan antara hasil yang dicapai dengan peran serta tenaga kerja per satuan waktu (lazimnya per jam), demikian pula kinerja sebagai ungkapan output, efesiensi serta efektivitas sering dihubungkan dengan produktivitas, sehingga kinerja karyawan adalah hasil kerja secara kualitatif dan kuantitatif yang dicapai oleh seorang karyawan dalam melaksanakan tugasnya sesuai dengan tanggung jawab yang diberikan kepadanya".

Pendapat lain tentang kinerja dikemukakan oleh Mathis dan Jackson, seperti dikutip oleh Achmad Amin (2012: 45) yang menyatakan bahwa "kinerja pada dasarnya adalah apa yang dilakukan atau tidak dilakukan karyawan. Kinerja karyawan adalah yang mempengaruhi seberapa banyak mereka memberi kontribusi kepada organisasi, antara lain: kuantitas output, kualitas output, jangka waktu output dan kehadiran di tempat kerja”.
Untuk melihat sejauh mana prestasi dan pencapaian yang telah diraih seorang tenaga kependidikan dalam periode tertentu diperlukan ukuran-ukuran rasional sebagai indikator suatu prestasi. Ukuran tersebut merupakan dasar suatu penilaian untuk meningkatkan kualitas dan kuantitas kinerja. Menurut Mathis \& Jackson (2011:378) untuk mengukur kinerja dapat menggunakan indikatorindikator (a) Kuantitas kerja, (b) Kualitas kerja, (c) Kehadiran, dan (d) Kemampuan bekerja sama

\section{KEPUASAN KERJA}

Robbins (2011: 102), mengemukakan bahwa "kepuasan kerja adalah suatu sikap umum seorang individu terhadap pekerjaanya. Kepuasan kerja merupakan sekumpulan perasaan, keyakinan, dan pikiran tentang bagaimana respon terhadap pekerjaannya. Hartatik (2014: 223) "mengatakan bahwa kepuasan kerja pada dasarnya merupakan salah satu aspek psikologis yang mencerminkan perasaan seseorang terhadap pekerjaannya. Ia akan merasa puas dengan adanya kesesuaian antara kemampuan, keterampilan dan harapannya dengan pekerjaan yang dia hadapi".

Wexley dan Yukl (Priansa, 2016:298) mengemukakan tiga teori kepuasan kerja, yaitu discrepancy theory, equity, theory, dan two factor theory.

\section{KOMPENSASI}

Dessler (1997:85) menyatakan bahwa "kompensasi merupakan salah satu bentuk pembayaran atau imbalan yang diberikan kepada karyawan dan timbul dari dipekerjakannya karyawan itu”. Hasibuan (2016:54) mendefinisikan kompensasi sebagai semua pendapatan yang berbentuk uang, barang 
langsung atau tidak langsung yang diterima karyawan sebagai imbalan atas jasa yang diberikan kepada perusahaan".

Izhari dkk (2019:308) menyampaikan bahwa kompensasi memiliki 10 tujuan, yaitu: (a) Ikatan kerjasama, (b) Kepuasan kerja, (c) Pengadaan efektif, (d) Motivasi kerja, (e) Stabilitas karyawan, (f) Disiplin, (g) Pemenuhan kebutuhan ekonomi, (h) Pengkaitan kompensasi dengan produktivitas kerja, (i) Pengkaitan kompensasi dengan sukses perusahaan, dan (j) Pengakaiatan antara keseimbangan keadilan pemberian kompensasi.

Veithzal Rivai (2011:356) membagi kompensasi dalam dua kelompok, yaitu kompensasi finansial dan non finansial. Kompensasi finansial dapat dibagi lagi kedalam dua kelompok, yaitu langsung dan tidak langsung. Sedangkan kompensasi non finansial dapat berupa pekerjaan dan lingkungan pekerjaan. Selanjutnya Veithzel Rivai (2011: 357) menyampaikan bahwa untuk menilai kompensasi terdapat empat indikator yang dapat digunakan, yaitu: (a) Gaji dan upah (baik yang diterima oleh pegawai karena kompensasinya terhadap perusahaan), (b) Insentif (tambahan kompensasi diluar gaji dan upah diberikan oleh perusahaan), (c) Fasilitas (kompensasi yang diberikan oleh pihak perusahaan kepada pegawai sebagai penunjang kelancaran untuk bekerja dan memotivasi pegawai agar semangat bekerjanya), (d) Tunjangan (kompensasi tambahan yang diberikan berdasarkan kebijakan perusahaan terhadap semua pegawai dalam usaha untuk meningkatkan kesejahteraan pegawai, seperti tunjangan kinerja, tunjangan kesehatan, tunjangan pendidikan)

\section{PENEMPATAN KERJA}

Suwatno (2008: 138) berpendapat bahwa “penempatan kerja adalah untuk menempatkan karyawan sebagai unsur pelaksana pekerjaan pada posisi yang sesuai dengan kemampuan, kecakapan dan keahliannya".

Penempatan kerja merupakan salah satu upaya menyalurkan keterampilan tenaga kependidikan secara lebih baik melalui penempatan tenaga kependidikan pada jabatan yang paling cocok untuk mencapai kepuasan kerja dan prestasi maksimal.

Mangkuprawira (2011: 166-170) menyatakan bahwa, ada dua cara penempatan kerja yaitu recruitment dan inplacement. Recruitment dengan cara menarik tenaga baru dari luar organisasi sedangkan inplacement adalah tenaga kependidikan yang sudah ada diberikan tugas atau posisi baru. Ada tiga jenis penempatan internal, yaitu: (a) Promosi, (b) Alih Tugas, dan (c) Demosi.

Tujuan menempatkan tenaga kependidikan pada jabatan yang sesuai dengan minat dan kemampuannya adalah agar dia menjadi lebih mampu menggali keterampilan terbaiknya, menjadi lebih efisien dalam menunaikan tugas yang menjadi tanggung jawabnya, juga untuk meningkatkan keterampilan dan kemampuannya dalam bekerja, selain itu juga rencana penempatan kerja harus memiliki tujuan berdasarkan kebutuhan (Sastrohadiwiryo, 2002: 166)

Ada beberapa faktor yang perlu diperhatikan dalam megukur penempatan kerja. Werther \& Davis (Suwatno, 2003: 129) mengemukakan beberapa dimensi dan indikator dalam penempatan kerja, yaitu faktor: (a) Prestasi Akademis, (b) Pengalaman, (c) 
Kesehatan Fisik dan Mental, (d) Status Perkawinan, dan (e) Usia.

\section{KERANGKA BERFIKIR DAN HIPOTESIS}

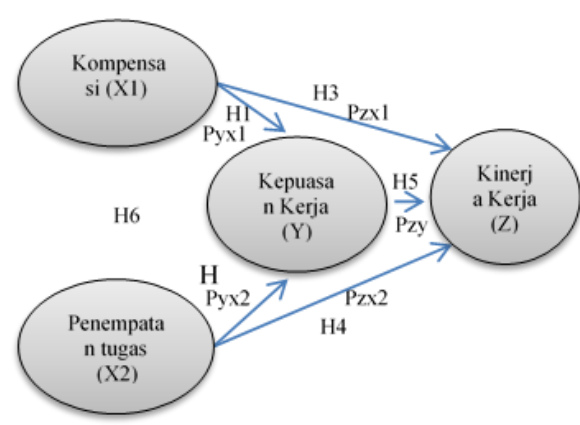

Bagan 1 Kerangka Berfikir

\section{HIPOTESIS}

Diduga terdapat pengaruh signifikan

H1 : dan positif kompensasi terhadap kepuasan kerja

Diduga terdapat pengaruh signifikan

H2 : dan positif penempatan tugas terhadap kepuasan kerja

Diduga terdapat pengaruh signifikan

H3 : dan positif kompensasi terhadap kinerja karyawan

Diduga terdapat pengaruh signifikan

H4 : dan positif penempatan tugas terhadap kinerja karyawan

Diduga terdapat pengaruh signifikan

H5 : dan positif kepuasan kerja terhadap kinerja karyawan

Diduga terdapat pengaruh signifikan

H6 : dan positif kompensasi terhadap penempatan tugas

Teradapat pengaruh signifikan dan

H7 . positif kepuasan kerja sebagai variabel intervening terhadap kinerja karyawan.

\section{METODE PENELITIAN}

\section{DESAIN PENELITIAN}

Tujuan dari penelitian ini adalah untuk menyajikan hubungan antar variabel, untuk memvalidasi teori, membuat prediksi, dan untuk menggeneralisasi. Teori digunakan sebagai standar untuk menentukan apakah suatu fenomena terjadi atau tidak.

Penelitian ini menggunakan pendekatan kuantitatif yang memadukan dua cara berfikri induktif dan deduktif (Suradika dan Wicaksono, 2019: 30) dengan metode eksplanatori untuk melihat hubungan antara variabel-varibel penelitian (Suradika, 2000: 22).

Data didapat secara langsung dari tenaga kependidikan Universitas "MJ" melalui pengambilan sampel yang mewakili populasi. Data yang telah diperoleh dari penelitian dimanfaatkan untuk pengujian terhadap hipotesis.

\section{POPULASI DAN SAMPEL}

Populasi dalam penelitian ini adalah Tenaga Kependidikan yang berstatus karyawan tetap pada Universitas "MJ" dan sudah bekerja lebih dari 3 tahun berjumlah 218 tenaga kependidikan. Dalam menghimpun sampel, digunakan teknik proporsional random sampling. Menurut Sugiyono (2015:92) "Proporsional random sampling merupakan teknik pengambilan sampel yang memberikan ke sempatan sama kepada semua anggota secara proporsional”. Sampel yang diuji harus mewakili populasi dan representatif. Berdasarkan rumus Slovin (Riduan dan Akdon, 2009: 254), diperoleh jumlah sampel sebanyak 68,5 dibulatkan menjadi 69 .

\section{TEKNIK PENGUMPULAN DATA \\ - PENGISIAN KUESIONER}

Kuesioner adalah cara mengumpulkan data melalui sejumlah peryataan tertulis yang akan dijawab responden. Indikator yang dijadikan acuan dalam membuat pernyataan/pertanyaan mengguna-kan skala likert yang memiliki jawaban dari sangat positif sampai sangat negatif dan dibuat nilainya (Sugiono, 2009:133):

1) Sangat Setuju diberi skor 5

2) Setuju diberi skos 4 
3) Ragu-ragu diberi skor 3

4) Tidak setuju 2

5) Sangat tidak setuju $\quad 1$

\section{- OBSERVASI}

Sutrisno Hadi seperti dikutip Sugiono (2009: 203) menyatakan bahwa observasi dapat dimanfaatkan jika objek yang diteliti adalah perilaku manusia, proses kerja, gejalagejala alam dengan sampel yang tidak terlalu besar.

\section{TEKNIK ANALISIS DATA}

Penelitian ini memakai metode analisis data WarpPLS (Partial Least Square) Versi 7.0, dengan tahapan analisis sesuai Solimun dkk. (2017:110) sebagai berikut ini:

1) Merancang Model Struktural (Inner Model)

2) Merancang Model Pengukuran (Outer Model)

3) Mengkonstruksi Diagram Jalur

4) Konversi Diagram Jalur ke Sistem Persamaan

5) Estimasi: Outer Model dan Inner Model

6) Evaluasi Goodness of Fit

7) Pengujian Hipotesis

\section{HASIL PENELITIAN}

- UJI OUTER MODEL

\section{VALIDITAS KONVERGEN}

Tabel 12 Combined Loading And Cross-Loading

\begin{tabular}{|c|c|c|c|c|c|}
\hline & $\mathbf{Z}$ & $\mathbf{Y}$ & $\mathbf{X} 1$ & $\mathbf{X} 2$ & $\begin{array}{l}P \\
\text { value }\end{array}$ \\
\hline Z1.1 & 0.791 & -0.03 & $\begin{array}{l}- \\
0.124\end{array}$ & $\begin{array}{l}- \\
0.079\end{array}$ & $<0.001$ \\
\hline Z1.2 & 0.872 & $\begin{array}{l}- \\
0.268\end{array}$ & 0.118 & 0.018 & $<0.001$ \\
\hline Z1.3 & 0.802 & $\begin{array}{l}- \\
0.302\end{array}$ & 0.028 & 0.265 & $<0.001$ \\
\hline Z1.4 & 0.863 & $\begin{array}{l}- \\
0.073\end{array}$ & -0.06 & 0.125 & $<0.001$ \\
\hline Z1.5 & 0.908 & 0.016 & $\begin{array}{l}- \\
0.098\end{array}$ & 0.127 & $<0.001$ \\
\hline
\end{tabular}

\begin{tabular}{|c|c|c|c|c|c|}
\hline Z1.6 & 0.84 & $\begin{array}{l}- \\
0.263\end{array}$ & $\begin{array}{l}- \\
0.106\end{array}$ & 0.369 & $<0.001$ \\
\hline Z1.7 & 0.849 & $\begin{array}{l}- \\
0.177\end{array}$ & 0.159 & $\begin{array}{l}- \\
0.051\end{array}$ & $<0.001$ \\
\hline Z1.8 & 0.83 & 0.354 & $\begin{array}{l}- \\
0.099\end{array}$ & -0.3 & $<0.001$ \\
\hline Z1.9 & 0.711 & 0.36 & 0.096 & $\begin{array}{l}- \\
0.183\end{array}$ & $<0.001$ \\
\hline $\begin{array}{l}\text { Z1.1 } \\
0 \\
\end{array}$ & 0.858 & 0.431 & 0.094 & $\begin{array}{l}- \\
0.324\end{array}$ & $<0.001$ \\
\hline Y.1 & 0.409 & 0.785 & $\begin{array}{l}- \\
0.197\end{array}$ & 0.262 & $<0.001$ \\
\hline Y.2 & 0.005 & 0.806 & $\begin{array}{l}- \\
0.279\end{array}$ & 0.266 & $<0.001$ \\
\hline Y.3 & -0.04 & 0.898 & $\begin{array}{l}- \\
0.122\end{array}$ & $\begin{array}{l}- \\
0.009\end{array}$ & $<0.001$ \\
\hline Y.6 & $\begin{array}{l}- \\
0.003 \\
\end{array}$ & 0.878 & 0.312 & $\begin{array}{l}- \\
0.265\end{array}$ & $<0.001$ \\
\hline Y.7 & $\begin{array}{l}- \\
0.369\end{array}$ & 0.775 & 0.278 & $\begin{array}{l}- \\
0.232\end{array}$ & $<0.001$ \\
\hline X1.1 & $\begin{array}{l}- \\
0.105\end{array}$ & $\begin{array}{l}- \\
0.178\end{array}$ & 0.783 & $\begin{array}{l}- \\
0.045\end{array}$ & $<0.001$ \\
\hline $\mathrm{X} 1.2$ & $\begin{array}{l}- \\
0.049\end{array}$ & $\begin{array}{l}- \\
0.208\end{array}$ & 0.8 & 0.064 & $<0.001$ \\
\hline X1.4 & $\begin{array}{l}- \\
0.071\end{array}$ & $\begin{array}{l}- \\
0.451 \\
\end{array}$ & 0.708 & $\begin{array}{l}- \\
0.066\end{array}$ & $<0.001$ \\
\hline X1.5 & 0.285 & $\begin{array}{l}- \\
0.141\end{array}$ & 0.625 & $\begin{array}{l}- \\
0.287\end{array}$ & $<0.001$ \\
\hline $\mathrm{X} 1.7$ & 0.142 & 0.336 & 0.717 & 0.195 & $<0.001$ \\
\hline X1.8 & $\begin{array}{l}- \\
0.192 \\
\end{array}$ & 0.281 & 0.754 & 0.043 & $<0.001$ \\
\hline X1.9 & 0.047 & 0.333 & 0.782 & 0.049 & $<0.001$ \\
\hline X2.1 & $\begin{array}{l}- \\
0.188\end{array}$ & 0.122 & -0.05 & 0.836 & $<0.001$ \\
\hline $\mathrm{X} 2.2$ & $\begin{array}{l}- \\
0.068 \\
\end{array}$ & 0.07 & $\begin{array}{l}- \\
0.107 \\
\end{array}$ & 0.903 & $<0.001$ \\
\hline $\mathrm{X} 2.3$ & $\begin{array}{l}- \\
0.234\end{array}$ & 0.066 & 0.02 & 0.793 & $<0.001$ \\
\hline X2.4 & $\begin{array}{l}- \\
0.373 \\
\end{array}$ & 0.062 & $\begin{array}{l}- \\
0.089\end{array}$ & 0.787 & $<0.001$ \\
\hline $\mathrm{X} 2.5$ & $\begin{array}{l}- \\
0.147\end{array}$ & 0.059 & $\begin{array}{l}- \\
0.091 \\
\end{array}$ & 0.916 & $<0.001$ \\
\hline X2.6 & 0.3 & $\begin{array}{l}- \\
0.143\end{array}$ & 0.11 & 0.859 & $<0.001$ \\
\hline X2.7 & 0.38 & $\begin{array}{l}- \\
0.132 \\
\end{array}$ & 0.024 & 0.819 & $<0.001$ \\
\hline X2.8 & 0.447 & 0.1 & $\begin{array}{l}- \\
0.083\end{array}$ & 0.777 & $<0.001$ \\
\hline X2.9 & $\begin{array}{l}- \\
0.114\end{array}$ & $\begin{array}{l}- \\
0.093\end{array}$ & 0.083 & 0.731 & $<0.001$ \\
\hline $\begin{array}{l}\text { X2.1 } \\
0 \\
\end{array}$ & 0 & $\begin{array}{l}- \\
0.127\end{array}$ & 0.212 & 0.777 & $<0.001$ \\
\hline
\end{tabular}

Berdasarkan tabel 1 nilai outer model atau korelasi antar konstruk setiap variabel yaitu $\mathrm{X} 1, \mathrm{X} 2$, Y dan Z memiliki nilai > 30 untuk semua combined loading dan cross loading 
dengan $p$-value, $<0.001$. dengan demikian pengukuran semua variabel adalah valid dan signifikan terhadap konstruk.

Validitas konvergen bertujuan untuk mengkonfirmasi pengukuran konstruk. Solimun dkk (2017: 115) memberikan rule of thumb loading factor yang dipandang bermakna jika lebih besar sama dengan 0.30. Dan jika loading factor dapat dikatakan signifikan apabila $p$-value lebih kecil dari $\mathrm{P}<$ 0.001 .

\section{VALIDITAS DISKRIMINAN}

Tabel 13 Correlation Among L.Vs. With Sq. Rts. Of Aves

\begin{tabular}{|l|l|l|l|l|}
\hline & $\mathbf{Z}$ & $\mathbf{Y}$ & $\mathbf{X} 1$ & $\mathbf{X} 2$ \\
\hline $\mathrm{Z}$ & 0.834 & 0.692 & 0.452 & 0.702 \\
\hline $\mathrm{Y}$ & 0.692 & 0.83 & 0.718 & 0.733 \\
\hline $\mathrm{X} 1$ & 0.452 & 0.718 & 0.74 & 0.672 \\
\hline $\mathrm{X} 2$ & 0.702 & 0.733 & 0.672 & 0.822 \\
\hline
\end{tabular}

Pada tabel 2 hasil uji validitas diskriminan dapat dijelaskan bahwa untuk variabel kompensasi (X1) mempunyai akar AVE 0.74 ; korelasinya dengan variabel lain sebesar $0.452,0.718$ dan 0.672 , sehingga variabel $\mathrm{X} 1$ memenuhi validitas diskriminan. Variabel penempat-an kerja (X2) memiliki akar AVE 0.822 ; korelasinya dengan variabel lain sebesar $0.702,0.733$ dan 0.672 sehingga variabel X2 memenuhi validitas diskriminan. Variabel kepuasan kerja (Y) mempunyai akar AVE 0.83 ; korelasinya dengan variabel lain yaitu $0.692,0.718$ dan 0.733 , sehingga variabel $\mathrm{Y}$ memenuhi validitas diskriminan. Begitu juga dengan variabel kinerja (Z) memiliki akar AVE 0.834; korelasinya dengan variabel lain yaitu $0.692,0.718$ dan 0.733 , sehingga variabel $\mathrm{Z}$ memenuhi validitas diskriminan.

\section{RELIABILITAS}

Tabel 14 Composite Reliability Coefficient, Cronbach's Alpha Coefficient And AVE

\begin{tabular}{|l|l|l|l|l|}
\hline No & & $\begin{array}{l}\text { Composite } \\
\text { Reliability } \\
\text { Coefficient }\end{array}$ & $\begin{array}{l}\text { Cronbach's } \\
\text { Alpha Coef- } \\
\text { ficient }\end{array}$ & AVE \\
\hline 1. & X1 & 0.898 & 0.871 & 0.548 \\
\hline 2. & X2 & 0.954 & 0.946 & 0.675 \\
\hline 3. & Y & 0.896 & 0.863 & 0.689 \\
\hline 4. & Z & 0.956 & 0.951 & 0.698 \\
\hline
\end{tabular}

Nilai composite reliability coefficient yang baik adalah $\geq 0.70$ (Solimun 2017). Tabel 3 menunjukkan bahwa masing-masing konstruk composite reliability coefficient untuk variabel $\mathrm{X} 1, \mathrm{X} 2$ dan $\mathrm{Y}$ serta $\mathrm{Z}$ memenuhi standar yang telah ditetapkan yakni $>0.8$.

Solimun (2017:117) menjelaskan bahwa cronbach's alpha coefficients $>0.5$ masih dapat diterima walaupun termasuk katagori kurang. Sedangkan cronbach's alpha coefficients $<0.4$ merupakan realibitas sangat rendah dan tidak dapat diterima.

Selanjutnya dapat dilihat kembali setiap konstruk cronbach's alpha coefficients untuk variabel X1, X2, dan Y serta Z memenuhi standar yang telah ditetapkan yakni $>0.8$. Sedangkan untuk nilai AVE variabel Kompensasi (X1) sebesar 0.548, variabel Penempatan Kerja (X2) sebesar 0.675, variabel Kepuasan Kerja (Y) sebesar 0.689, variabel Kinerja (Z) sebesar 0.696.

Demikain juga untuk konstruk AVE variabel X1, X2, dan Y serta Z memenuhi standar yang telah ditetapkan yakni $>0.6$ (Solimun, 2017:117).

\section{UJI INNER MODEL}

Model fit and quality indinces hasil penelitian melalui analisis dengan software 
WarpPLS 7.0 dapat dilihat pada tabel 4.5 berikut:

Tabel 15 Model Fit And Quality Indences

\begin{tabular}{|c|c|c|c|c|}
\hline No. & $\begin{array}{l}\text { Fit and } \\
\text { Qty } \\
\text { Indnce }\end{array}$ & $\begin{array}{l}\text { Kriteria } \\
\text { Fit }\end{array}$ & $\begin{array}{l}\text { Hasil } \\
\text { Ana- } \\
\text { lisis }\end{array}$ & Ket \\
\hline 1 & APC & $\mathrm{P}<0.05$ & $\begin{array}{l}0.403 \\
\mathrm{P}<0.001\end{array}$ & Baik \\
\hline 2 & ARS & $\mathrm{P}<0.05$ & $\begin{array}{l}0.590 \\
\mathrm{P}<0.001\end{array}$ & Baik \\
\hline 3 & AARS & $\mathrm{P}<0.05$ & $\begin{array}{l}0.578 \\
\mathrm{P}<0.001\end{array}$ & Baik \\
\hline 4 & AVIF & $\begin{array}{l}\text { accept }<= \\
5 \\
\text { ideally }<= \\
3.3\end{array}$ & 2.671 & Ideal \\
\hline 5 & AFVIF & $\begin{array}{l}\text { accept }<= \\
5 \\
\text { ideally }<= \\
3 .\end{array}$ & 2.781 & Ideal \\
\hline 6 & GoF & $\begin{array}{l}\text { small }>= \\
0.1 \\
\text { medium } \\
>=0.25 \\
\text { large }>= \\
0.36\end{array}$ & 0.620 & Large \\
\hline 7 & SPR & $\begin{array}{l}\text { Accept }>= \\
0.7 \\
\text { ideally }=1\end{array}$ & 1.000 & Ideal \\
\hline 8 & RSCR & $\begin{array}{l}\text { accept }>= \\
0.9 \\
\text { ideally }=1\end{array}$ & 1.000 & Ideal \\
\hline 9 & SSR & $\begin{array}{l}\text { accept }>= \\
0.7\end{array}$ & 1.000 & Ideal \\
\hline 10 & NLBCD & $\begin{array}{l}\text { accept >= } \\
0.7\end{array}$ & 1.000 & ideal \\
\hline
\end{tabular}

Tabel 4 model fit and quality indences dapat disimpulkan bahwa hasil analisis penelitian ini, 3 dari 10 model memiliki goodness of fit yang baik sesuai dengan kriteria yang telah ditetapkan, 6 model memiliki goodness of fit yang ideal dan 1 model memiliki goodness of fit large, tetapi hal ini bersifat rule of thumb sehingga selayaknya tidak berlaku secara kaku dan mutlak" (Solimun dkk, 2017: 117).

\section{UJI R-SQUARE}

Table 1 Hasil Nilai R-Square

\section{R-squared coefficients}

\begin{tabular}{|l|l|l|l|}
\hline KIN_Z & KK_Y & $\begin{array}{l}\text { KOM_ } \\
\text { X1 }\end{array}$ & $\begin{array}{l}\text { PK_- } \\
\text { X2 }\end{array}$ \\
\hline & 0.657 & & \\
\hline
\end{tabular}

Adjusted R-squared coefficients

\begin{tabular}{|l|l|l|l|}
\hline KIN_Z & KK_Y & $\begin{array}{l}\text { KOM_ } \\
\text { X1 }\end{array}$ & $\begin{array}{l}\text { PK_- } \\
\text { X2 }\end{array}$ \\
\hline & 0.646 & & \\
\hline
\end{tabular}

Berdasarkan tabel 5 di atas menunjukan bahwa nilai $R$-square variabel professional judgment sebesar 0.657. Nilai R-square adjusted sebesar 0.646 mempunyai arti bahwa variabilitas konstruk kepuasan kerja yang dapat dijelaskan oleh variabilitas konstruk $\mathrm{X} 1$, dan X2 sebesar $65.7 \%$ sedangkan sisanya $34.3 \%$ dijelaskan oleh variabel lain yang tidak ditelit dalam penelitian ini.

\section{UJI HIPOTESIS}

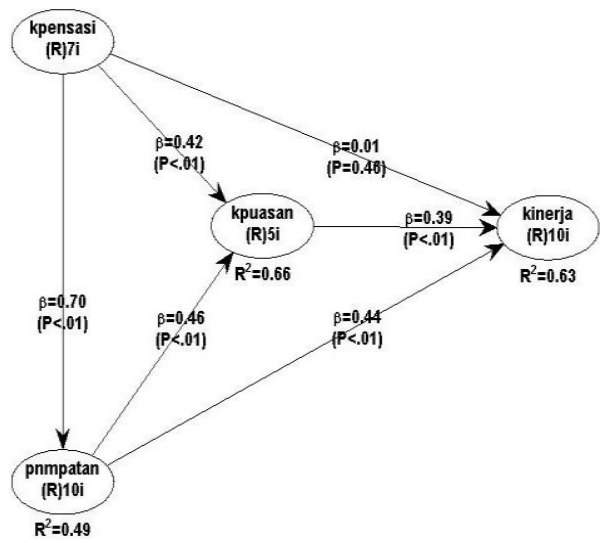

Bagan 2 Model Struktural Pengujian Hipotesis

Pada tahap uji hipotesis ini, estimasi signifikansi parameter akan memberikan informasi bagaimana pengaruh antar variabel penelitian. Batasan menerima hipotesis yang diajukan adalah $P$ value $<0.05$. $P$ value $>$ 0.05 hipotesis ditolak. Estimasi uji model struktural dapat dilihat pada tabel di bawah ini:

Tabel 16 Hasil Pengujian Hipotesis

\begin{tabular}{|l|l|l|l|l|}
\hline No & Variabel & $\begin{array}{l}\text { Koef } \\
\text { Path }\end{array}$ & $\begin{array}{l}\text { P- } \\
\text { Value }\end{array}$ & Ket \\
\hline
\end{tabular}




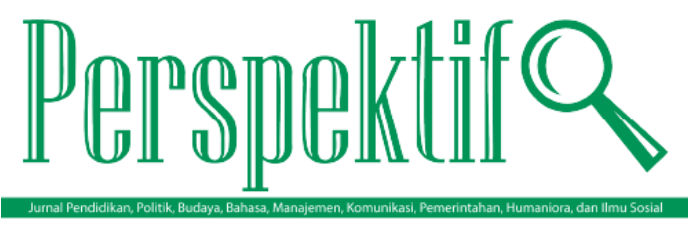

\begin{tabular}{|l|l|l|l|l|l|l|}
\hline 1 & $\mathrm{X} 1$ & & $\mathrm{Y}$ & 0.42 & $<0.001$ & $\begin{array}{l}\text { Signif- } \\
\text { ikan }\end{array}$ \\
\hline 2 & $\mathrm{X} 2$ & & $\mathrm{Y}$ & 0.46 & $<0.001$ & $\begin{array}{l}\text { Signif- } \\
\text { ikan }\end{array}$ \\
\hline 3 & $\mathrm{X} 1$ & & $\mathrm{Z}$ & 0.012 & 0.461 & $\begin{array}{l}\text { Tidak } \\
\text { Signif- } \\
\text { ikan }\end{array}$ \\
\hline 4 & $\mathrm{X} 2$ & & $\mathrm{Z}$ & 0.439 & $<0.001$ & $\begin{array}{l}\text { Signif- } \\
\text { ikan }\end{array}$ \\
\hline 5 & $\mathrm{Y}$ & & $\mathrm{Z}$ & 0.387 & $<0.001$ & $\begin{array}{l}\text { Signif- } \\
\text { ikan }\end{array}$ \\
\hline 6 & $\mathrm{X} 1$ & & $\mathrm{X} 2$ & 0.689 & $<0.001$ & $\begin{array}{l}\text { Signif- } \\
\text { ikan }\end{array}$ \\
\hline 7 & $\mathrm{X} 1$ & $\mathrm{Y}$ & $\mathrm{Z}$ & 0.469 & $<0.001$ & $\begin{array}{l}\text { Signif- } \\
\text { ikan }\end{array}$ \\
\hline 8 & $\mathrm{X} 2$ & $\mathrm{Y}$ & $\mathrm{Z}$ & 0.321 & $<0.001$ & $\begin{array}{l}\text { Signif- } \\
\text { ikan }\end{array}$ \\
\hline
\end{tabular}

4. HASIL DAN PEMBAHASAN

1) Kompensasi berpengaruh signifikan terhadap kepuasan kerja, hal ini sesuai dengan teory equity di mana keadilan terhadap pemberian kompensasi sudah sesuai dengan yang diharapkan dan juga sesuai dengan teori discrepancy yang menyatakan bahwa kompensasi yang diberikan tidak sama antara tenaga kependidikan satu dengan yang lainnya. Pemberian kompensasi dapat meningkatkan kepuasan kerja. Universitas "MJ" harus memperhatikan pengaturan kompensasi secara adil dan rasional. Bila tenaga kependidikan memandang pemberian kompensasi tidak memadai, maka kepuasan kerja cenderung akan menurun. Pemberian kompensasi pada tenaga kependidikan yang berprestasi akan memberikan kepuasan kerja, sehingga tenaga kependidikan tersebut dapat memberikan output yang baik bagi Universitas "MJ". Hasil penelitian ini mendukung hasil penelitian dari Sunarta (2019).

2) Penempatan kerja berpengaruh signifikan terhadap kepuas an kerja, hasil penelitian ini sesuai teori Equity, dimana teori ini

didasarkan pada asumsi bahwa orangorang dimotivasi oleh keinginan untuk diperlakukan secara adil dalam pekerjaan. Didalam penempatan sumber daya manusia, dimana proses penempatan ini adalah tahap penentuan setelah dilakukan seleksi yang bertujuan untuk memberi peluang yang sama kepada setiap tenaga kependidikan untuk berkembang dan dapat menuangkan kreativitas dan kemampuannya dalam menyelesaikan segala bentuk tugas dan tanggung jawab yang diberikan. Jika penempatan tenaga kependidikan sudah sesuai dengan prinsip the right man on the right place maka tenaga kependidikan tersebut akan bekerja dengan baik. Penempatan tenaga kependidikan yang sesuai dengan latar belakang pendidikan dan pengalaman kerja sebelumnya akan meningatkan semangat dalam bekerjas. Hasil penelitian ini mendukung hasil penelitian dari Nimas dan Mirwan dkk (2018).

3) Kompensasi tidak berpengaruh signifikan terhadap Kinerja Tenaga Kependidikan, P Values pada penelitian ini $>$ dari 0.05 $(0.461>0.05)$. Penelitian ini tidak berhasil mendefinisikan dari teori equity dan discrepancy. Pemberian kompensasi baik langsung ataupun kompensasi tidak langsung tidak memiliki pengaruh langsung terhadap kinerja. Azas-azas keadilan dan kewajaran dalam pemberian kompensasi juga tidak memiliki pengaruh langsung terhadap kinerja.

4) Penempatan kerja berpengaruh signifikan terhadap kinerja tenaga kependidikan, hasil penelitian ini sesuai teori equity, dimana teori ini didasarkan pada asumsi bahwa individu dimotivasi oleh keinginan 
untuk diperlakukan secara adil dalam pekerjaan. Menurut Hasibuan (2005), “penempatan kerja harus didasarkan pada job description dan job specification yang telah ditentukan serta berpedoman kepada prinsip the right man on the right place and the right man behind the job. Sehingga, sangat penting peran penempatan tenaga kependidikan terkait pencapaian tujuan Universitas "MJ" melalui kinerja tenaga kependidikan yang sesuai dengan keahlian dan kemampuan. Hasil penelitian ini mendukung hasil penelitian dari Darwis dkk (2015) dan Tanto Wijaya dan Fransisca Andreani (2015).

5) Kepuasan kerja berpengaruh signifikan terhadap Kinerja Tenaga Kependidikan, hasil penelitian ini sesuai teori equity, dimana teori ini didasarkan pada asumsi bahwa individu dimotivasi oleh keinginan untuk diperlakukan secara adil dalam pekerjaan. Serta teori discrepancy dan two factor theory dimana kepuasan kerja seseorang bergantung pada discrepancy antara expectation, needs or values dengan apa yang menurut perasaannya atau persepsinya telah diperoleh atau dapat dicapai melalui pekerjaan. Kepuasan kerja pada tenaga kependidikan akan mempengaruhi tingkat produktivitas kerja dan hasil akhir yang merupakan juga keberhasilan atau kemajuan Universitas "MJ". Hasil penelitian ini mendukung hasil penelitian dari Dani dan Djambur dkk (2014).

6) Kompensasi berpengaruh signifikan terhadap penempatan kerja, hasil penelitian ini sesuai teori equity, dimana teori ini didasarkan pada asumsi bahwa orangorang dimotivasi oleh keinginan untuk diperlakukan secara adil dalam pekerjaan. Kompensasi diberikan bertujuan memberikan rangsangan dan motivasi kepada tenaga kerja untuk meningkatkan prestasi kerja, serta efisiensi dan efektivitas kerja. Kepuasan kerja tenaga kependidikan terletak pada salah satu faktor, yaitu kompensasi yang merupakan segala sesuatu yang diterima tenaga kerja sebagai imbalan atas pekerjaan yang mereka lakukan. Hasil penelitian ini mendukung hasil penelitian dari Tanto Wijaya dan Fransisca Andreani (2015).

7) Pengaruh kepuasan kerja sebagai variabel intervening berpengaruh signifikan terhadap kinerja tenaga kependidikan, kepuasan kerja dapat diungkapkan bahwa apa yang membuat sebagian individu lebih puas terhadap suatu pekerjaan daripada individu lainnya. Tenaga kependidikan yang memiliki kepuasan terhadap hasil kerjanya, akan lebih bersemangat melakukan pekerjaan berikutnya, dengan demikian akan dihasilkan kinerja yang tinggi dalam tiap hasil kerjanya.

\section{KESIMPULAN}

Berdasarkan analisis dan pembahasan sebelumnya dapat disimpulan bahwa, kompensasi berpengaruh signifikan terhadap kepuasan kerja, dibuktikan dengan nilai $p$ values $<$ dari $0.05(0.001<0.05)$ dengan coefficient path 0.42. Pemberian kompensasi baik kompensasi langsung dan kompensasi tidak langsung secara bersama-sama, dengan memperhatikan azas-azas keadilan dan kewajaran, dapat meningkatkan kepuasan kerja sebesar $42 \%$ dan sisanya sebesar $58 \%$ dipengaruhi oleh faktor lain yang tidak diteliti pada penelitian ini. Artinya jika kompensasi 
dinaikan 42\%, makan kepuasan kerja juga akan naik sebesar $42 \%$. Hal ini berbeda ketika kompensasi dihubungkan secara langsung kepada kinerja, besar $p$ values kompensasi terhadap kinerja 0.461. $(P$ value $>0.05)$ dengan nilai coefficient path sebesar 0.012, dengan demikian kompensasi berpengaruh tidak signifikan terhadap kinerja. Pemberian kompensasi baik langsung ataupun kompensasi tidak langsung tidak memiliki pengaruh langsung terhadap kinerja. Azas-azas keadilan dan kewajaran dalam pemberian kompensasi juga tidak memiliki pengaruh langsung terhadap kinerja. Akan tetapi, jika kompensasi dihubungkan secara tidak langsung terhadap kinerja melalui kepuasan kerja, menghasilkan $p$ value $<0.001(0.001<0.005)$, artinya secara tidak langsung kompensasi mempengaruhi kinerja melalui kepuasan kerja. Nilai coefficient path dari hubungan antara kompensasi, kepuasan kerja dan kinerja sebesar 0.469, dengan demikian kompensasi memberikan pengaruh secara tidak langsung kepada kinerja melalui kepuasan kerja sebesar $46,9 \%$.

Penempatan kerja berpengaruh signifikan terhadap kepuasan kerja. Hal ini dapat dilihat dari nilai $p$ values $<$ dari $0.05(0.021<0.05)$ dengan coefficient path sebesar 0.46. Penempatkan kerja memberikan pengaruh sebesar $46 \%$ terhadap kepuasan kerja. Kepuasan kerja masih dapat ditingkat lagi melalui variabel penempatan kerja dengan meningkatkan indikator-indikator penempatan kerja, empat diantaranya adalah pertama, menempatkan tenaga kependidikan sesuai dengan latar belakang pendidikan yang dimilikinya. Kedua, dengan menyeseuaikan penempatan kerja dengan pengalaman kerjanya. Ketiga, dengan mempertimbangkan kesehatan fisik dan mental dan yang keempat dengan memperhatikan usia tenaga kependidikan. Penempatan kerja juga berpengaruh signifikan terhadap kinerja. Hal ini dapat dilihat dari $p$ values $<$ dari $0.05(0.001<0.05)$ dengan coefficient path sebesar 0.439. Indikator-indikator penempatan kerja seperti disebut diatas secara langsung juga mempengaruhi kinerja. Sama halnya jika penempatan kerja dihubungkan secara tidak langsung kepada kinerja melalui kepuasan kerja, menghasilkan coefficient path sebesar $<0.001$, artinya secara tidak langsung penempatan kerja mempengaruhi kinerja melalui kepuasan kerja. Nilai coefficient path dari hubungan antara penempatan kerja, kepuasan kerja dan kinerja sebesar 0.321, dengan demikian kompensasi memberikan pengaruh secara tidak langsung kepada kinerja melalui kepuasan kerja sebesar $32.1 \%$.

Kepuasan kerja berpengaruh terhadap kinerja, $p$ values antara kepuasan kerja dan kinerja $<0.001$ dengan coefficient path sebesar 0.387. Dalam penelitian ini ada dua indikator yang digunakan untuk meng ukur kepuasan kerja yaitu pekerjaan itu sendiri dan promosi. Kedua indikator ini secara bersamasama memberikan pengaruh kepada kinerja sebesar 38.7\%. Kepuasan kerja juga memberikan peranan yang baik sebagai variabel intervening memiliki pengaruh signifikan terhadap kinerja. Kepuasan kerja dapat memediasi pengaruh kompensasi dan penempatan kerja terhadap kinerja.

Penelitian ini mengkonfirmasi teori equity pada variabel yang diteliti, bahwa tenaga kependidikan Universitas "MJ" dimotivasi oleh keinginan untuk diperlakukan secara 
adil dalam pekerjaan. Kompensasi yang diberikan bertujuan untuk merangsang tenaga kependidikan untuk meningkatkan prestasi kerja, efisiensi dan efektivitas kerja. Kepuasan kerja terletak pada salah satu faktor yaitu, kompensasi yang merupakan segala sesuatu yang diterima tenaga kependidikan sebagai imbalan atas pekerjaan yang mereka lakukan. Two factor theory, teori ini menjelaskan bahwa kepuasan kerja berbeda dengan ketidakpuasan kerja. Artinya kepuasan atau ketidakpuasan terhadap pekerjaan itu tidak merupakan suatu variabel yang berkelanjutan.

Kompensasi berpengaruh tidak signifikan terhadap kinerja tenaga kependidikan, kompensasi yang diberikan tidak sesuai dengan hasil kinerja yang dicapai. Hal ini harus menjadi perhatian dan fokus bagi pimpinan Universitas “MJ", sehingga kompensasi yang diberikan dapat meningkatkan kinerja tenaga kependidikan.

Ada dua cara untuk meningkatkan kinerja tenaga kependidikan:

1) Pemberian kompensasi diharapkan dapat diukur melalui capaian kinerja yang dihasilkan dan diinformasikan kepada tenaga kependidikan agar mereka mendapat rangsangan untuk meningkatkan kinerja (kompensasi berbasis kinerja).

2) Universitas "MJ" memfokuskan pada pemenuhan kepuasan kerja tenaga kependidikan secara terus menerus yang akan berdampak pada peningkatan kinerja.

\section{REFERENSI}

Akdon dan Riduwan. 2009. Aplikasi Statistika dan Metode Penelitian untuk Administrasi dan Manajemen. Bandung: Dewa Ruci.

Amin Ahmad. 2012. Manajemen Kinerja Pemerintah Daerah, Cet. 12, Yogyakarta: LaksBang PRESSINDO.

Danang Sunyoto, 2012. Manajemen Sumber Daya Manusia, Yogyakarta: CAPS.

Dessler, Gary. 1997. Manajemen Sumberdaya Manusia. Jakarta: PT. Prenhallindo.

Gaol L, Jimmy. 2014. A to Z Human Capital: Manajemen Sumber Daya Manusia. Jakarta: PT. Grasindo.

Hartatik Indah Puji. 2014. Buku Praktis Mengembangkan SDM. Cet. I, Yogyakarta: Laksana.

Hasibuan, Malayu S.P. 2016. Manajemen Sumber Daya Manusia. Edisi Revisi. Jakarta: Penerbit PT Bumi Aksara.

Izhari Fadhilah dkk, 2019. Evaluasi Kinerja Insani pada Perusahaan. Jakarta: Campustaka.

Kaswan. 2012. Manajemen Sumber Daya Manusia untuk Keunggulan Bersaing Organisasi. Edisi Pertama. Yogyakarta: Graha Ilmu.

L. Mathis, Robert \& H. Jackson, John. 2011. Human Resource Management (edisi 10). Jakarta: Salemba Empat.

Mangkuprawira, S.Tb. 2011. Manajemen Sumber Daya Manusia Strategik. Bogor: Ghalia Indonesia.

Priansa dan Suwatno. 2013. Manajemen SDM dalam Prganisasi Publik dan Bisnis. Bandung: Alfabeta.

Rivai, Veithzal. 2011. Manajemen Sumber Daya Manusia untuk Perusahaan: dari Teori ke Praktik. Jakarta: RajaGrafindo Persada.

Robbins, Stephen dan Judge, Timothy. 2011. Perilaku Organisasi (Organizasional Behavior). Jakarta: Salemba Empat.

Sastrohadiwiryo, Siswanto. 2002. Manajemen Tenaga Kerja Indonesia. Jakarta: Bumi Aksara. 
Solimun, Achmad, Adji. R. F, Nurjannah. 2017. Metode Statistika Multivariat Pemodelan Persamaan Struktural (SEM) Pendekatan WarpPLS. Malang: UB Press.

Sudaryono. 2017. Pengantar Manajemen Teori dan Kasus. Jakarta: Buku Seru.

Sugiono. 2009. Metode Penelitian Bisnis (pendekatan kuantitatif dan $R \& D$ ). Cet ke 14, Bandung: Alfabeta.

Sugiyono. 2015. Metode Penelitian Kombinasi (Mix Methods). Bandung: Alfabeta.
Suradika, Agus. (2000). Metode Penelitian Sosial. Jakarta: UMJ Press.

Suradika, A dan Wicaksono, D. (2019). Metodologi Penelitian. Tangerang Selatan: UM Jakarta Press.

Suwatno dan Donni Juni Priansa. 2016. Manajemen SDM dalam Organisasi Publik dan Bisnis. Bandung: Alfabeta.

Suwatno. 2003. Manajemen Sumber Daya Manusia. Jakarta: Erlangga. 